\title{
Development of Stunting Early Detection Kit for Children under Two Years: Validity and Reliability
}

\author{
Aphrodite Nadya Nurlita ${ }^{1}$, Maria Wigati ${ }^{1}$, Mubasysyir Hasanbasri ${ }^{1}$, Jumarko ${ }^{2}$, \\ Siti Helmyati ${ }^{3,4^{*}}$ \\ ${ }^{1}$ Department of Biostatistic, Epidemiology, and Population Health, Faculty of Medicine, \\ Public Health, and Nursing, Gadjah Mada University, Yogyakarta 55281, Indonesia \\ ${ }^{2}$ Seyegan Public Health Center, Seyegan, Sleman Yogyakarta 55561, Indonesia \\ ${ }^{3}$ Department of Nutrition, School of Health Nutrition, Faculty of Medicine, Public Health, and Nursing, \\ Gadjah Mada University, Yogyakarta 55281, Indonesia \\ ${ }^{4}$ Center for Health and Human Nutrition, Faculty of Medicine, Public Health, and Nursing, \\ Gadjah Mada University, Yogyakarta 55281, Indonesia
}

\begin{abstract}
This study aimed to determine validity and reliability of the new developed Stunting Early Detection Kit (SEDEK). This study was a cross-sectional study. A total sample of 30 children under two years from a Posyandu in Seyegan, Yogyakarta, was involved in the study. Every child was measured using SEDEK and infantometer-WHO Length for Age Growth Chart as the gold standard to find out its validity. Validity was determined by sensitivity, specificity, and predictive value. Reliability in this study was measured by intra-rater reliability, by comparing the first measurement and the second measurement from a rater using SEDEK. The intra-rater reliability determined using the Intraclass Correlation Coefficient (ICC). The results showed no significant difference between length measurements using SEDEK and the gold standards ( $p>0.05$ ). The SEDEK sensitivity was $80 \%$, specificity $85 \%$, positive predictive value $72.7 \%$, negative predictive value $89.5 \%$. SEDEK reliability is demonstrated by ICC of 0.781 . However, this study suggest that the current SEDEK version has not met the required sensitivity and positive predictive value of more than $80 \%$ so that it can be used as a detection tool. Further research is needed to improve the quality of SEDEK so that the SEDEK improved version can be used at the community-based health facilities level.
\end{abstract}

Keywords: aged 0-24 months, nutrition screening tool, reliability, stunting, validity

\section{INTRODUCTION}

Stunting is considered one of the biggest nutritional problems that affects $21.9 \%$ or 149 billion children under five in 2018 globally (UNICEF/WHO/The World Bank 2019). Based on Basic Health Research 2018, the prevalence of stunting in children under five years was $30.8 \%$, while the target prevalence as stated in the National Medium-Term Development Plan (RPJMN) is $28 \%$ (MoH RI 2018).

Stunting defined as child's length or height according to their age is below -2 SDs of the WHO child growth standards median (de Onis \& Branca 2016). In addition to their physical growth faltering, stunted children may also have impaired cognitive function, poor motor skills, decreased physical capacity, and neurodevelopment, and even reduced productivity and cause economic loss in the future (Prendergast \& Humprey 2014; Stewart 2013; Renyoet et al. 2016). Therefore, it is important detect stunting earlier especially in children under two years old to prevent negative consequences.

Early detection of stunting can be done at Community Based Health Post or commonly known as Posyandu in Indonesia, this can done by empowering Posyandu cadres or health volunteers (Adistie et al. 2018). However, this is not an easy task, since health volunteers in Posyandu mostly are not health care workers it can affect the accuracy of early stunting detection results. Research conducted by Adistie et al. (2018), Fuada et al. (2014), and Hadi et al. (2019) showed that cadres have been less accurate in measuring and evaluating

"Corresponding Author: tel: +6227454775, email: siti.helmyati@gmail.com 
the growth measure Length-for-Age $\mathrm{Z}$ score (LAZ). These inaccuracies are possibly caused by several reasons, including lack of training so that cadres become less skilled, non-routine length measurements so that cadres are not accustomed, difficulties in plotting the growth curve when assessing LAZ, or the quality of length measurement tools that don't comply with WHO standards (Adistie et al. 2018; de Onis \& Branca 2016; Fuada et al. 2014)

Some posyandu do not have a length measurement tool that complies with WHO standards. For Posyandu that do not have infantometers, the child's length is measured using microtoise, tailor measuring tape, metline, measuring instruments made of wood, or other measuring devices developed before. Some of the measuring instruments that have been developed are portable height measuring instruments, multifunctional measuring instruments, and growth mats. However, these tools have several weaknesses, such as difficulty in ensuring child position correctly. These tools validity's also unknown and these tools are not developed with instruments to interpret length measurement results (Amareta et al. 2016; Basset \& RuelBergeron 2012; Sinaga et al. 2018).

To solve those problems, a nutrition detection or screening that meets the easily understood and fast-to-use criteria must be developed. Furthermore, these tools must produce valid and reliable results. Validity is described as tools accuracy to detect the "true" value of the measurement. Reliability show tools consistency to measure what will be measured (Gleason et al. 2010; Jamaiyah et al. 2010; Sinaga et al. 2018). A valid detection or screening tool will help provide preventive action more quickly to prevent future growth failures (Maxim et al. 2014).

Based on the identified problems, the researchers aimed to determine the quality of the newly developed Stunting Early Detection Kit (SEDEK). The researchers highlight SEDEK validity and reliability based on sensitivity, specificity, positive predictive value, and negative predictive value to detect the "true" value of the measurement. This research is essential so that SEDEK, an early detection tool that will be developed, can be a precise and accurate early stunting detection tool. It is expected that the use of SEDEK can help health workers take stunting preventive action quickly and precisely.

\section{METHODS}

\section{Design, location, and time}

The design of this study was crosssectional. The research was conducted in Kamal Wetan, Seyegan, Sleman, Yogyakarta in January 2020 until March 2020.

\section{Sampling}

The study population was all of the children registered at Posyandu Kamal Wetan, Seyegan, Yogyakarta. According to Murti (2011), the subjects involved in testing the newly developed measuring instrument were 20-30 people. Subjects involved in this study were as many as 30 children. The criteria were children aged 0 to 24 months, registered as members of Posyandu Kamal Wetan, and the parents willing to provide consent for their children participation in this study.

\section{Tool design}

The development of SEDEK begins with designing a length mat and a nutritional status disc. SEDEK's length mat is made of thick, strong, and safe plastic material with a size of $120 \times 20$ $\mathrm{cm}$. It was inspired by the existing infantometer but with some innovation. There is a semicircular head brace at the top of the mat to put the child's head, while at the bottom, there are footrests. On the mat, there is an illustration depicting the child's position when measured. The growth measurement mats have a measurement scale up to $100 \mathrm{~cm}$ with an accuracy of $1 \mathrm{~mm}$.

SEDEK's length mat comes with a nutritional status disc. SEDEK's nutritional status disc has two sides. The blue side to interpret boys LAZ and the pink side for female LAZ. On both sides, there is a large circle that shows children's age and a smaller circle to determine their nutritional status. Determination of these numbers refers to the WHO-2005 Length-forAge Child Growth Standards.

The prototype of SEDEK's design was then discussed with nutritionists, anthropometrists, and design experts to be evaluated. Based on the evaluation results, the first design was then redesigned. Some improvements made were the illustration's change to make it more attractive and more clear depiction of the child's position. The writing of the stunting category on the disc was made clearer, and the scale on the mat was printed 
thicker. The second design was then discussed again with nutritionists, anthropometrist, and design expert where it was then approved by those experts and used in this study. SEDEK Growth Mat and Nutritional Status Discs used in this study are presented in figure 1 .

\section{Data collection}

There are two step to determine stunting in children. First children's length need to be measured and then intepret the length measurement result to Length-For-Age Z Score (LAZ). The length was obtained by measuring length with SEDEK's length mat and infantometer, while LAZ was obtained using the SEDEK's nutritional status disc and the WHO-2005 length-for-age Child Growth Standard chart. Infantometer and the WHO-2005 length-for-age Growth Chart are the gold standards. The data on the children's age were obtained from interviews with parents/ guardians.

There were two stations to measure the child's length which were attended by one operator in each station. The first station used to measure child's length using SEDEK and the other one use to measure the child's length using Kenko ${ }^{\circledR}$ Infantometer with an accuracy of $0.1 \mathrm{~cm}$. Each child was measured twice with each tool, with an interval between measurement about 5 untill 10 minutes or until the baby was calmer to be measured.

To use the SEDEK for measurement two operators were needed. One operator as a rater who was responsible for ensuring the child's position and took the measurement, while the other as an assistant helped the rater to hold the child's position and recorded the measurement to minimize recall bias.

Before taking the child's length measurement, the mat should be stretched on a dry, flat surface. The rater must ensure that the mat was straight and not wavy. Hat or headdress, shoes, and other thick clothing were removed from the child. The child was then placed on their back on the mat with the head attached to the top of the headboard. A rater stood on the side of the mat and ensures the position of the baby's body was straight, the back was attached to the mat, and the position of the child's feet was perpendicular to the footboard with the toes pointing upwards, while the assistant stood on the side of the top of the child's head to hold the child's chin and cheeks.

To measure the child's length, the child's legs should be straight thus their knee were pressed gently and the footboard was slide towards the child's feet. The rater who stood on the sides of the mat should ensure that the footboard was attached perpendicular to the child's feet. After that, the rater reads the child's length while the assistant recorded the child's length

The results of the length measurement were interpreted using the nutritional status disc. To operate it, first, the rater should determined the child's age (in months), the rotated the small circle according to the child's age. When the child's body length was within the range of numbers in the normal category, then the child's body length
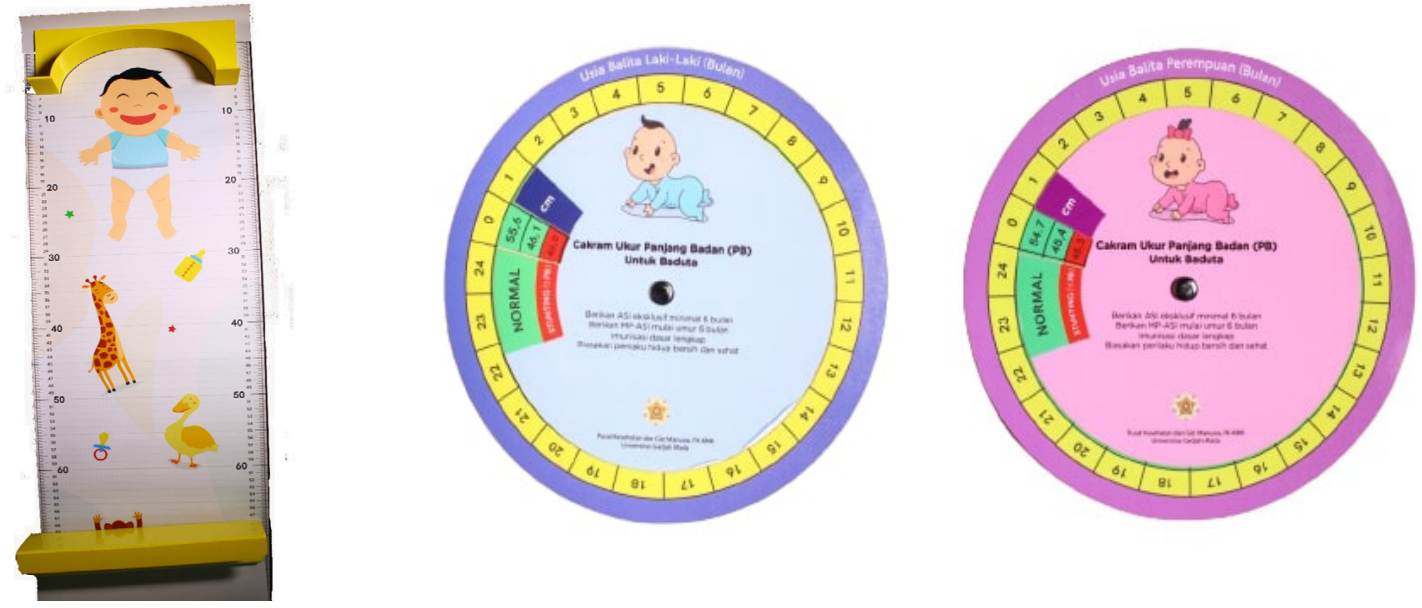

Figure 1. Stunting early detection kit (SEDEK) 
was normal, whereas when the child's body length was less than the number in the stunting category, then the child was considered as stunted.

\section{Data analysis}

Data analysis was performed using STATA version 12. Difference in mean of data from children's length measurements using SEDEK and infantometers were tested using a t-test. The t-test are significant if the $p<0.05$ at the $95 \%$ confidence level.

A validity test was used to determine the accuracy of stunting detection kits compared to the gold standard. The validity analysis was done by performing a cross-tabulation table between the gold standard and the SEDEK. The crosstabulation displayed the sensitivity, specificity, Positive Predictive Value (PPV), and Negative Predictive Value (NPV) of the SEDEK in comparison to the gold standard.

The consistency was measured by intrarater reliability using ICC. An ICC coefficient of less than 0.5 indicated poor reliability, $0.5-<0.75$ indicated moderate reliability, good reliability was indicated by an index between 0.75 and 0.9 , and values greater than 0.90 indicated excellent reliability (Koo \& Li 2016). This study was approved by the Ethics Commission of the Faculty of Medicine, Public Health, and Nursing with Number KE / FK / 0004 / EC / 2019.

\section{RESULTS AND DISCUSSION}

The subject were 30 children aged 0-24 months from Padukuhan Kamal Wetan, Seyegan. Most of the subject were female (63.33\%). The youngest subject were 3 months old and the oldest were 23 months old (Table 1).

Table 1. Subject characteristic

\begin{tabular}{|c|c|c|}
\hline Characteristic & $\mathrm{n}$ & $\%$ \\
\hline \multicolumn{3}{|l|}{ Sex } \\
\hline Boy & 11 & $36.67 \%$ \\
\hline Girl & 19 & $63.33 \%$ \\
\hline \multicolumn{3}{|l|}{ Age } \\
\hline $0-12$ months & 15 & $50 \%$ \\
\hline 13-24 months & 15 & $50 \%$ \\
\hline
\end{tabular}

\section{Children length's measurement}

Stunting is determined by measuring the length of the subject's body first then interpreting the measurement results to lengthfor-age nutritional status. As seen in Table 2, 30 measurement taken by the two measurement tools, only 1 (3.33\%) measurement presented the same results and the remaining measurement were not similiar.

Table 3 shows that the mean difference of length measurment is $0.03 \mathrm{~cm}$. The mean of children length measured using SEDEK is $72.32 \pm 6.26 \mathrm{~cm}$, while the mean using the infantometer is $72.29 \pm 6.26 \mathrm{~cm}$. The $\mathrm{t}$ test result showed that the differences in measurement between the gold standar and the SEDEK was not significantly different $(\mathrm{p}>0.05)$.

The difference can be caused by systemic errors, such as imperfect calibration of the

Tabel 2. Difference of measurement between SEDEK and infantometer

\begin{tabular}{lcc}
\hline \multicolumn{1}{c}{ Delta $(\mathrm{cm})$} & $\mathrm{n}$ & $\%$ \\
\hline$-2.00-2.50$ & 0 & 0 \\
$-1.60--2.00$ & 0 & 0 \\
$-1.10--1.50$ & 2 & 6.67 \\
$-0.60--1.00$ & 3 & 10 \\
$-0.10--0.50$ & 9 & 30 \\
$-0.05-0.10$ & 0 & 0 \\
$0.0-0.0$ & 1 & 3.33 \\
$0.05-0.10$ & 3 & 10 \\
$0.10-0.50$ & 7 & 23.33 \\
$0.60-1.00$ & 2 & 6.67 \\
$1.10-1.50$ & 2 & 6.67 \\
$1.60-2.00$ & 0 & 0 \\
$2.10-2.50$ & 1 & 3.33 \\
Total & 30 & 100.00 \\
\hline${ }^{*}$ SEDEK: Stunting early detection kit & &
\end{tabular}

"SEDEK: Stunting early detection kit 
Validity and reliability of stunting early detection kit

Table 3. Child's length measurement using SEDEK and infantometer

\begin{tabular}{lccccc}
\hline & SEDEK & Infantometer & & $\begin{array}{c}\text { Mean Difference } \\
(95 \% \mathrm{CI})\end{array}$ & ${ }^{*} \mathrm{p}$ \\
\cline { 2 - 3 } & Means \pm SD $(\mathrm{cm})$ & Means \pm SD $(\mathrm{cm})$ & & 0.03 \\
Lenght & $72.32 \pm 6.26$ & $72.29 \pm 6.26$ & & $(-0.26-0.33)$ & 0.7951 \\
\hline
\end{tabular}

${ }^{*}$ Based on t-test; SEDEK: Stunting early detection kit

measurement tool (Mony et al. 2016). In addition, techincal difficulties to keep the child still and stretched during the assement should also be taken into account (Jamaiyah et al. 2010).

\section{Validity of stunting early detection kit (SEDEK)}

The SEDEK was compared with the infantometer and WHO-2005 length-for-age Child Growth Standard chart as the gold standard. Stunting measurement using the SEDEK found that 11 of 30 subjects were considered short based on their or stunted (36.67\%). Meanwhile, the remaining 19 subjects had normal nutritional status. However, the gold standard measurement found fewer stunted children $(33.33 \%)$.

The World Health Organization (WHO) recommends the use of an infantometer and WHO-2005 length-for-age Child Growth Standard chart to detect stunting in children under two years old (WHO 2008). However, limitations of using those tools are, it requires skilled workers to ensure accuracy (Fuada et al. 2014; Hadi et al. 2019).

Cross-tabulation displayed in Table 4, found that the sensitivity value of SEDEK is $80 \%$ and the specificity is $85 \%$. This sensitivity value means those children who were identified as stunting using SEDEK, $80 \%$ of them were also identified as stunted by infantometer. Meanwhile, the specificity value is $85 \%$ reflects the number of children identified as non stunted was also identified as non stunted by the infantometer. Analysis of the positive predictive value showed that $72.7 \%$ of children who were detected stunted is actually stunting and the negative predictive value showed that $89.5 \%$ of children who were not identified as stunted are actually did not have linear growth disorder based on their LAZ score.

However, ideally, a good early detection tool or screening tool should have sensitivity, specificity, and predictive value of more than $80 \%$ (Glascoe 1991). The analysis shows that SEDEK has a good validity (sensitivity $80 \%$, specificity $85 \%$, PPV $72.7 \%$, and NPV $89.5 \%$ ). However, the sensitivity and PPV are lower than the specificity and NPV. Low sensitivity and positive predictive values indicate many falsepositive cases. High false-positive cases can lead to unnecessary treatment, while high falsenegative cases can cause delayed preventive actions (Sudja et al. 2019). In this study, we found 3 children who misclassified as stunted (false-positive) and 2 children who misclassified as normal (false-negative). The number of falsepositive cases can be minimized by testing the

Table 4. Validty of SEDEK

\begin{tabular}{lllcl}
\hline & & \multicolumn{2}{c}{$\begin{array}{c}\text { Length-for-age based on } \\
\text { infantometer }\end{array}$} & \multirow{2}{*}{ Total (n) } \\
\cline { 3 - 4 } & & Stunting (n) & Normal (n) & \\
\hline \multirow{3}{*}{ Length-for-age based on SEDEK } & Normal & 2 & 17 & 19 \\
& Stunting & 8 & 3 & 11 \\
& Total & 10 & 20 & 30
\end{tabular}

Se: $80 \%$; Sp: $85 \%$; PPV: $72.7 \%$; NPV: $89.5 \%$

${ }^{*}$ Se:Sensitivity; Sp:Specificity; PPV:Positive Predictive Value; NPV:Negative Predictive Value SEDEK: Stunting early detection kit 
tool in areas with a higher prevalence of stunting (Trevethan 2017).

Several studies that aim to develop and test the accuracy of early detection tools in Indonesia have been previously studied. A study by Sinaga et al. (2018) in North Sumatera which developed a wall growth chart showed a high validity (sensitivity $91 \%$, specificity $92 \%$, PPV $82 \%$, and NPV 98\%). Another similar study by Sudja et al. (2019) which develop a wall KMS (Kartu Menuju Sehat) shows sensitivity 66\%, specificity $73.6 \%$, PPV $73.6 \%$, and NPV $90.3 \%$. Compared to the two studies, SEDEK has lower sensitivity, specificity, and predictive value. This might be due to the difference in the age group of children. The wall KMS developed by Sinaga et al. (2018) and Sudja et al. (2019) was tested in children aged 4 to 5 years and 6 to 12 years, while SEDEK was studied in children aged 0 to 24 months. As mentioned before, measuring children's length can be more difficult for keeping children position still and stretched (Jamaiyah et al. 2010)

\section{Reliability of stunting early detection kit (SEDEK)}

Intra-rater reliability shows agreement between measurement by the same measurer (Gleason et al. 2010). Intraclass Correlation Coefficient (ICC) was used to determine the agreement between the two measurements. The ICC of the first measurement and the second measurement is 0.781 . This shows that there is a good agreement between the first measurement and the second measurement of the same rater. A similar study by Jamaiyah et al. (2010), in Malaysia, which measures reliability of a length measurement tools in children under two years old, showed excellent reliability with an ICC value of 0.9 . This could be due to the better measurement technique or more skilled rater.

According to Hashemi-Nejad et al. (2013) intra-rater reliability could be affected by an error in reading scales, changes in the subject's position, or rater experiencing fatigue because repeated measuring. Reliability can be improved through periodical training and standardizing measurement procedures (Mony et al. 2016). Standardizing measurement procedures can be done by doing repeated measurement with more than three times on 10 to 20 subjects. The measurement results were then compared with the results of measurements made by an anthropometrist (de Onis et al. 2004).

The SEDEK mat material was also not ideal, whenever it is rolled for too long, a roll mark will appear which causes wavy texture and the length become less straight for the next measurement. Rater should straighten the length mat before using it. Therefore further research is needed related to the material selection for SEDEK.

The present study is the first study to develop and test the validity and reliability of an early stunting detection kit for children under two years old in Indonesia. However, this study has several limitations in the sample selection and the tool's reliability measurement. The subject determination in screening tool tests for validity and reliability should considers the prevalence of the disease (Zaidi et al. 2016). However in this study, there is no available data of the stunting prevalence in Kamal Wetan Village, therefore subject determination used the minimum sample size of 30 subjects. Moreover, the time interval for reliability of the measurement in this study is too close and measurements were only taken twice. According to Hockenberry and Wilson (2018) and Streiner et al. (2015) measuring children's length should ideally be done three times with the interval between measurement is between two to fourteen days. It makes further research necessary to improve the quality of SEDEK. This study should also be done in areas with higher stunting prevalence. This study also did not examine the inter-rater and test-retest reliability which also affects the quality of SEDEK.

The findings from this research imply the need further research and practice. To develop stunting early detection kits or screening tools, it is advisable to consider the stunting prevalence in the population being tested as well as the level of skill from the cadre or user in using such tools. It is important for the tool's validation and reliability testing so that the final tool can be well utilized in community-based facilities settings.

\section{CONCLUSION}

The validity test of SEDEK is determined by its sensitivity, specificity, and predictive value. Compared to the standard infantometer, SEDEK has a sensitivity of $80 \%$, specificity $85 \%$, positive predictive value $72.7 \%$, and 
Validity and reliability of stunting early detection kit

negative predictive value $89.5 \%$. The intra-rater reliability of SEDEK indicated by the ICC value is 0.781 , which means SEDEK utilization shows a good agreement between the first and second measurement by the same operator. However, based on its current validity and reliability test result, SEDEK has not yet been recommended as a stunting detection tool for children aged 0-24 months. Several limitations that affect SEDEK's validity and reliability are the number of subjects involved and the measurement of its reliability as well as the material quality of the mat. Further research is needed to improve the accuracy and quality material of SEDEK so that the SEDEK can utilized in larger community settings.

\section{ACKNOWLEDGEMENT}

This study is supported by Hibah Penelitian Terapan Unggulan Perguruan Tinggi (PTUPT), Ministry of Research, Technolofy, and Higher Education no.1826/UN1/DITLIT/DITLIT/PT/2020 on behalf of Siti Helmyati.

\section{AUTHOR DISCLOSURES}

The authors have no conflict of interest.

\section{REFERENCES}

Adistie F, Lumbantobing VBM, Maryam NNA. 2018. Pemberdayaan kader kesehatan dalam deteksi dini stunting dan stimulasi tumbuh kembang pada balita. Media Karya Kesehatan 1(2). https://doi.org/10.24198/ mkk.v1i2.18863.

Amareta DI,Arum P,HikmahF. 2016. Peningkatan keterampilan kader dalam pengukuran panjang badan bayi sebagai upaya deteksi dini stunting di wilayah kerja puskesmas sumbersari. J-Dinamika Jurnal Pengabdian Masyarakat 1(1):9-13. https://doi. org/10.25047/j-dinamika.v1i1.128.g134.

Basset L, Ruel-Bergeron J. 2012. Promoting Healthy Child Growth and Development: Advances and Opportunities for Community-Based Nutrition Programs in Central America. Washington (USA): The World Bank.

de Onis M, Onyango AW, Broeck JVD, Chumlea WC, Martorell R. 2004. Measurement and standardization protocols for anthropometry used in the construction of a new international growth reference. Food and Nutrition Bulletin 25(Suppl 1):S27-S36. https://doi.org/10.1177/ $15648265040251 \mathrm{~S} 104$.

de Onis M, Branca F. 2016. Childhood stunting: A global perspective. Matern Child Nutr 12(S1):12-26. https://doi.org/10.1111/ mcn.12231.

Fuada N, Salimar, Irawati A. 2014. Kemampuan kader posyandu dalam melakukan pengukuran panjang/tinggi badan balita. Indonesian Journal of Health Ecology 13(3):229-239.

Glascoe FP. 1991. Developmental screening: Rationale, methods, and application. Infants \& Young Children 4(1): 1-10.

Gleason PM, Harris J, Sheean PM, Boushey CJ, Bruemmer B. 2010. Publishing nutrition research: Validity, reliability, and diagnostic test assessment in nutritionrelated research. J Am Diet Assoc 110 (3):409-419. https://doi.org/10.1016 /j.jada.2009.11.022.

Hadi A, Alfridsyah A, Affan I. 2019. Efektifitas deteksi stunting menggunakan KMS dinding indeks $\mathrm{TB} / \mathrm{U}$ pada anak usia 4-5 tahun di Sekolah PAUD. Aceh Nutrition Journal 4(1):70-74. https://doi. org/10.30867 /action.v4i1.160.

Hashemi-Nejad N, Choobineh A, Baneshi MR, Jafari-Roodbandi A. 2013. Intra-observer and Inter-observer reliability in direct anthropometry. Int J Occup Hyg 5(2):8288.

Hockenberry MJ, Wilson D. 2018. Wong's Nursing Care of Infants and Children E-Book. Missouri (USA): Elsevier Health Sciences.

Jamaiyah H, Geeta A, Safiza MN, Khor HL, Wang NF, Kee CC, Rahmah R, Ahmad AZ, Suzana S, Chen WS et al. 2010. Reliability, technical error of measurements and validity of length and weight measurements for children under two years old in Malaysia. Med J Malaysia 65(Supplement A):131-137.

Koo TK, Li MY. 2016. A guideline of selecting and reporting intraclass correlation coefficients for reliability research. J Chiropr Med 15(2):155-163. https://doi. org/10.1016/j.jcm.2016.02.012. 
[MoH RI] Ministry of Health Republic of Indonesia. 2018. Situasi Balita Pendek (Stunting) di Indonesia. Jakarta (ID): $\mathrm{MoH}$ RI.

Maxim LD, Niebo R, Utell MJ. 2014. Screening tests: A review with examples. Inhalation Toxicology 26(13):811-828. https://doi.or g/10.3109/08958378.2014.955932.

Mony PK, Swaminathan S, Gajendran JK, Vaz M. 2016. Quality assurance for accuracy of anthropometric measurements in clinical and epidemiological studies [Errare humanum est $=$ to err is human]. Indian J Community Med 41(2):98-102. https:// doi.org/10.4103/0970-0218.173499.

Murti B. 2011. Validitas dan Reliabilitas Pengukuran. Matrikulasi Program Studi Doktoral Fakultas Kedokteran. Surakarta: Universitas Negeri Sebelas Maret.

Prendergast AJ, Humphrey JH. 2014. The stunting syndrome in developing countries. Paediatr Int Child Health 34(4):250 265. https://doi.org/10.1179/204690551 4Y.0000000158.

Renyoet BS, Martianto D, Sukandar D. 2016. Potensi kerugian ekonomi karena stunting pada balita di Indonesia tahun 2013. J Gizi Pangan 11(3):247-254. https://doi. org/10.25182/jgp.2016.11.3.\%p.

Sinaga HT, Alfridsyah BS, Hadi A. 2018. A simple nutrition screening tool for detecting stunting of pre-schoolers: Development and validity assessment. Pakistan J Nutr 17(5):236-241. https://doi.org/10.3923/ pjn.2018.236.241.

Stewart CP, Iannotti L, Dewey KG, Michaelsen KF, Onyango AW. 2013.
Contextualising complementary feeding in a broader framework for stunting prevention. Maternal \& child nutrition 9(S2):27-45. https://doi.org/10.1111/ men. 12088 .

Streiner DL, Norman GR, Cairney J. 2015. Health Measurement Scales: A Practical Guide to Their Development and Use. Oxford (UK): Oxford University Press.

Sudja S, Sitanggang B, Shagti I, Purnawan AI. 2019. Sensitivity (Se) and specificity (Sp) anthropometric wall chart (Awc) $\mathrm{Tb} / \mathrm{U}$ for detecting stunting on children aged 6-12 Years. KnE Life Sciences. 210-221. https://doi.org/10.18502/kls.v4i15.5761.

Trevethan R. 2017. Sensitivity, specificity, and predictive values: Foundations, pliabilities, and pitfalls in research and practice. Front Public Health 5:307. https://doi. org/10.3389/fpubh.2017.00307.

[UNICEF/WHO/The WorldBank] United Nations International Children's Emergency Fund/ World Health Organization/The World Bank. 2019. Levels an Trends in Child Malnutrition: Key Findings of the 2020 Edition of the Joint Child Malnutrition Estimate. Geneva $(\mathrm{CH})$ : WHO.

[WHO] World Health Organization. 2008. Training Course on Child Growth Assesment. Geneva (CH): World Health Organization.

Zaidi SMH, Waseem HF, Ansari FA, Irfan M, Fahim S. 2016. Sample Size Estimation of Diagnostic Test Studies in Health Sciences. Proceedings of 14th International Conference on Statistical Sciences (page 239-246), 14-16th March 2016. Pakistan (PK): University Karachi. 